\title{
Longevity of starved bumblebee queens (Hymenoptera: Apidae) is shorter at high than low temperatures
}

\author{
SALLA-RIIKKa VESTERLUND ${ }^{1}$ and JOUNI SORVARI ${ }^{1,2}$ \\ ${ }^{1}$ Department of Biology, Section of Ecology, FI-20014 University of Turku, Finland; e-mail: salla.vesterlund@utu.fi \\ ${ }^{2}$ Department of Environmental Science, University of Eastern Finland, P.O. Box 1627, FI-70211 Kuopio, Finland; \\ e-mail: jouni.sorvari@uef.fi
}

Key words. Hymenoptera, Apidae, Bombus lucorum, bumblebee, spring temperature, starvation, Parasitellus fucorum, mites

\begin{abstract}
Northern bumblebees (Hymenoptera: Apidae) with annual lifecycles depend both on energy stores remaining in their fat body after diapause and a few spring flowering plants. Most temperate bumblebees emerge gradually over several months after winter depending on the species and within species on the location of the overwintering chamber (hibernaculum). Weather can either delay or promote emergence and nectar resources are needed to fuel flight at low ambient temperatures to find a nest site. Several phoretic mites use queens for transportation and have synchronized life cycles with their host species. Their presence on the body of bumblebees is usually harmless but can become harmful when the number of mites increases to hundreds per individual bee. High numbers of mites on queens may also indicate the queens are in poor condition. The effect of temperature and mite load on the time for which queens can survive (d) during a 25-day period of starvation were determined using newly emerged spring queens of B. lucorum. Queens collected from various locations in SW Finland were divided into four groups taking into account their initial load of Parasitellus fucorum mites: (A) $15^{\circ} \mathrm{C}$ and provided with only water; (B) $24^{\circ} \mathrm{C}$ and provided with only water; (C) $15^{\circ} \mathrm{C}$ and provided with pollen and nectar; (D) $24^{\circ} \mathrm{C}$ and provided with pollen and nectar. There were mites on $65 \%$ (50 out of 77 ) of the queens. All of the fed queens survived and starved queens died, with those kept at $24^{\circ} \mathrm{C}$ dying approximately 8 days before those kept at $15^{\circ} \mathrm{C}$. Queen weight or mite load had no effect on the length of the period for which they survived and there was no difference in the weights of the queens in the different mite load classes. Asynchrony between plants and insect as well as increased frost damage due to climate change may affect nectar availability in spring. Therefore, the survival and long term viability of bumblebee populations should be monitored during variable spring conditions.
\end{abstract}

\section{INTRODUCTION}

Northern species of bumblebees have an annual life cycle in which only the new queens hibernate after mating in late summer or autumn (Alford, 1978; Goulson, 2010; but see Stelzer et al., 2010). Single queens found new nests in the spring or early summer and depend both on energy stores remaining in their fat body after the diapause and nectar from a few flowering plants (Sladen, 1912; Free \& Butler, 1959; Alford, 1978). Some species in the subarctic and arctic areas are highly dependent on certain plants and appear $24 \mathrm{~h}$ after the blooming of the first willow catkins (Vogt et al., 1994). Most temperate bumblebees, however, emerge gradually over several months from late winter to midsummer depending on the species and within species on the location of the overwintering chamber (hibernaculum) (Alford, 1978). Weather can either delay or promote the emergence of bumblebee queens: the spring temperature must exceed $15^{\circ} \mathrm{C}$ before the emergence of the white-tailed bumblebee Bombus lucorum (Linnaeus) starts (Pekkarinen $\&$ Teräs, 1997). The spring queens need nectar to fuel flight at low ambient temperatures (Heinrich, 1975) to find suitable nest sites; later pollen is also needed for nest initiation (Pereboom, 2000; Pereboom et al., 2003; Goulson, 2010).

In two bumblebee species the queens disperse over distances ranging from $3000 \mathrm{~m}$ to $5000 \mathrm{~m}$ before founding a nest (Lepais et al., 2010). This includes the distance covered in mating, diapause, nest founding and foraging
(Goulson, 2010). During dispersal in spring, the queens are able to collect pollen from early flowering plants at greater distances than workers (Macior, 1968, 1994; Washitani et al., 1994). Several phoretic mites also use bumblebees for transportation and synchronize their life cycles with that of their hosts (Schwarz et al., 1996; Schwarz \& Huck 1997; Huck et al., 1998; Koulianos \& Schwarz, 1999; Chmielewski \& Baker, 2008). Mites attach themselves to new queens when they leave the nest in autumn and accompany them to hibernation sites (Eickwort, 1994; Schwarz et al., 1996; Huck et al., 1998). After overwintering with the host, the mites wait until the queen founds a new nest and then detach themselves and live in the nest (Goulson, 2010). Up to six species of mites have been found on overwintering queens (Schwarz et al., 1996). Mites of the family Parasitidae are generally found in forest litter, grassland humus, moss, decaying organic substrates and the nests of both small mammals and insects (Bhattacharyya, 1962; Micherdziński, 1969; Hyatt, 1980; Karg, 1993; Mašań \& Stanko, 2005; Lindquist et al., 2009). All holarctic species of Parasitellus are obligatory associates of bumblebees (Rozej et al., 2012). Parasitellus fucorum (De Geer) overwinters as a deutonymph and matures in the nests of bumblebees where they feed mainly on wax, pollen and nectar (Richards \& Richards, 1976; Schmid-Hempel, 1998; Koulianos \& Schwarz, 1999). In comparison with other phoretic species, Parasitellus are highly mobile and have 
a strong gnathosoma with functional palpi and chelicerae. Moreover, they are behaviourally adapted to living with bumblebees due to their quick reactions and good orientation ability (Chmielewski \& Baker, 2008). In the spring in Poland $70 \%$ of B. lucorum are infested with $P$. fucorum (Chmielewski \& Baker, 2008).

Females and deutonymphs of phoretic mites can affect their hosts negatively by consuming pollen (Chmielewski \& Baker, 2008), but oophagous and predatory protonymphs are more likely to have positive effects by reducing the abundance of other pollen-eating arthropod species in the nest (Schmid-Hempel, 1998). Although the presence of phoretic mites on the body of bumblebees is usually harmless, it can become harmful when the number of mites increases to hundreds or even thousands per individual bee (Chmielewski \& Baker, 2008), because they restrict their movement and flying ability. In addition, it is also possible that a high number of mites may indicate the queen is in poor condition.

Here, the effect of temperature and mite load on the length of time (d) newly emerged spring queens of B. lucorum (Hymenoptera: Apidae) can survive starvation is determined. The first hypothesis tested is that starved queens die sooner at high than low temperatures and that queen size (measured as fresh weight at the beginning of the experiment) affects the time for which they survive such that smaller queens die first. Also, we expect that queens with the highest mite load die first because the mites are either harmful to queens or the high numbers indicate the relatively poor condition of the queens.

\section{MATERIAL AND METHODS}

\section{Study design}

Queens of B. lucorum $(\mathrm{N}=80)$ were collected from various locations in South Western Finland during 22 $2^{\text {nd }}$ April $-1^{\text {st }}$ May 2012. Of these, 77 queens were used in the analyses and three were excluded due to drowning in the water dispenser (model commonly used in bird cages with a $100 \mathrm{ml}$ plastic water container outside and a $1 \mathrm{~cm}$ wide and $2 \mathrm{~cm}$ long drinking area inside the cage). The number of phoretic mites ( $P$. fucorum) on each queen was used to assign them to one of 3 classes: $0=$ no visible mites, $1=1-70$ mites, and 2=70-200 mites. The mites were counted in the field immediately after capturing the queen. The escape of mites was controlled with greenhouse insect traps (Silvalure, Silvandersson Sweden $\mathrm{AB}$ ) that were put under each individual queen's box. Each queen box was made out of a round 0.251 clear plastic container (diameter $10 \mathrm{~cm}$, height $12 \mathrm{~cm}$ ) held upside down with its lid at the bottom. Holes were drilled along the edge of the lid, which helped to keep the box clean of faeces. A $5 \mathrm{~cm}$ $\times 5 \mathrm{~cm}$ hole was cut in the bottom of the container (the top of the queen box) and a piece of $2 \mathrm{~mm}$ stainless steel wire mesh was glued on with warm glue to allow feeding and ventilation. For additional ventilation, $2 \mathrm{~mm}$ diameter holes were drilled in the walls of the container. A piece of cardboard was taped in the bottom to keep the container clean and dry.

Queens were divided into four groups taking into account their initial load of phoretic mites, so that in every group there would be approximately the same number of queens from all phoretic mite number classes. The mite number class was used later in the analysis as an indicator of individual queen's mite load. Group A $(\mathrm{N}=20)$ queens were kept at $15^{\circ} \mathrm{C}$ and only provided with water;

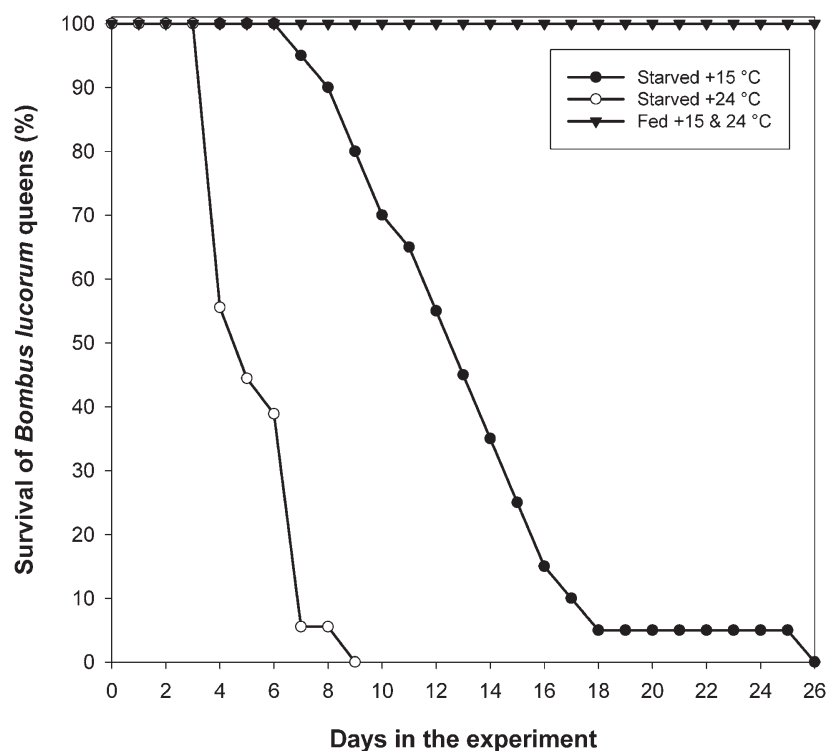

Fig. 1. The percentage survival of queens in the four treatment groups: (A) $15^{\circ} \mathrm{C}$ and provided only with water; (B) $24^{\circ} \mathrm{C}$ and provided only with water; (C) $15^{\circ} \mathrm{C}$ and provided with pollen and nectar; (D) $24^{\circ} \mathrm{C}$ and provided with pollen and nectar. The experiment was terminated on day 25 when the last of the queens that were starved died (i.e., none of them survived until day 26).

group $\mathrm{B}(\mathrm{N}=18)$ queens were kept at $24^{\circ} \mathrm{C}$ and only provided with water; group $\mathrm{C}(\mathrm{N}=20)$ queens were kept at $15^{\circ} \mathrm{C}$ and provided with both pollen (bee collected, fresh frozen) and nectar (Biobest: BioGluc); group D $(\mathrm{N}=19)$ queens were kept at $24^{\circ} \mathrm{C}$ and provided with both pollen and nectar.

The survival of queens was checked once a day until all the queens in groups A and B were dead. The fed queens (group C and D) were similarly checked for 25 days before transferring them to rearing facilities, where they were reared until they produced eggs and their first workers emerged, when the wooden nest boxes were placed out in the field.

\section{Statistical analysis}

All statistical analyses were made using statistical software SAS version 9.2 (SAS Institute, Cary, NC, USA). We used the generalized linear model in the GLIMMIX procedure with Poisson distribution and log link function. The number of days they survived was the dependent variable in this analysis, with queen weight, temperature treatment (groups A-D), mite load (classes $1-3)$ and their interactions as fixed effects. All interactions were non-significant and were excluded from the final model. Weight differences of queens in the different mite load classes were analyzed using an REML-based Mixed model.

\section{RESULTS}

There were mites on $65 \%$ (50 out of 77 ) of the queens. Survival time differed significantly between the groups $\left(F_{3,71}=94.46, P<0.0001\right.$; the Tukey's test for pair-wise differences, group $\mathrm{C}$ vs. D: $\mathrm{P}>0.99$, all other pair-wise tests between groups: $\mathrm{P}<0.0001$; Fig. 1). All of the fed queens (group $\mathrm{C}$ and $\mathrm{D}$ ) survived for 25 days. In contrast, all group A and B queens died within 25 days from the start of the experiment as expected. The temperature treatment clearly affected the time for which they survived such that queens died approximately 8 days (mean $7.8 \mathrm{~d}$ ) sooner at $24^{\circ} \mathrm{C}$ (group B) than at $15^{\circ} \mathrm{C}$ (group A) when 


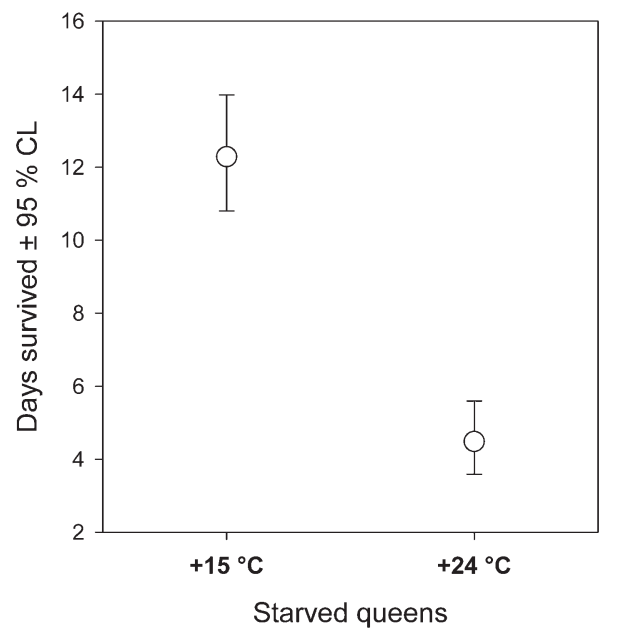

Fig. 2. The mean length of time (d) for which the bumblebee (Bombus lucorum) queens survived when only provided with water and starved at (A) $15^{\circ} \mathrm{C}$ and (B) $24^{\circ} \mathrm{C}$. The difference in the length of time they survived in the two treatments is significant $(\mathrm{P}<0.0001)$.

given no food (Fig. 2). However, there was no difference between the survival times when the queens were given nectar. Queen weight had no effect on the length of time for which they survived within the 25 days $\left(F_{1,71}=0.20\right.$, $P=0.65)$, neither had the mite load $\left(F_{1,71}=0.16, P=0.69\right)$. There was no difference in the weights of the queens in the different mite load classes $(1-3)\left(F_{2,74}=1.76, P=0.18\right)$. All interactions were non-significant and were excluded from the final model (treatment $\mathrm{x}$ weight $\mathrm{x}$ mite load $F_{3,61}=0.21$, $P=0.89$; weight $\mathrm{x}$ mite load $F_{1,64}<0.001, P=0.95$; mite load $\mathrm{x}$ treatment $F_{3,65}=0.29, P=0.83$; weight $\mathrm{x}$ treatment $\left.F_{3,68}=0.37, P=0.77\right)$. Group A and B queens were not seen drinking the water they were provided, but two individuals were excluded from the experiment after they were found either wet or drowned in the water dispenser.

\section{DISCUSSION AND CONCLUSIONS}

When given no food, the bumblebee queens survived for a shorter time at $24^{\circ} \mathrm{C}$ than at $15^{\circ} \mathrm{C}$. This was expected since body functions are faster and the overall energy expenditure higher in warm than cold conditions. There are some recent experimental studies in ecology, where temperature differences have affected the survival and use of energy reserves in social insects: boreal wood ants (Formica aquilonia) use their body fat resources faster at high than low temperatures and their overall survival also increased the greater their initial fat body resources (Sorvari et al., 2011). In Bombus terrestris, queen weights being greater than $0.6 \mathrm{~g}$ prior to diapause is important, but temperature (between $-5^{\circ} \mathrm{C}$ and $15^{\circ} \mathrm{C}$ ) seems to have no effect on survival during diapause under laboratory conditions (Beekman et al., 1998). In this experiment, the queens died only of hunger and accidental drowning. In nature, predation mostly by birds, especially in spring, increases the incidence of mortality (Forster-Johnson, 2002). The emerging queens may also carry mites and other parasites, but the $P$. fucorum mites studied here did not affect survival under laboratory conditions. There was no association between queen size or queen condition and the number of mites on the individuals. In addition, there was no indication of other causes of mortality, since it is highly unlikely that such causes of death would only affect groups A and B, since all the other queens (groups C and D) survived for 25 days. It is possible, however, that starvation may have affected the incidence of mortality due to an unknown parasite or virus and thus some other causes of death may have been overlooked in this study. The relatively short time for which the starved queens survived and the $100 \%$ survival of the fed queens, however, support starvation as the main cause of death.

The latest IPCC report predicts that the mean global temperature may rise by as much as $4.8^{\circ} \mathrm{C}$ during the next 100 years (IPCC, 2013). This is likely to alter the time of flowering and the whole pollination system, especially in the Northern Hemisphere: springtime warming is more likely to advance the phenology of plants than of insects (Forrest $\&$ Thomson 2011). The potential mismatch between insects and plants due to climate change may also depend on their different responses to, for example, chilling, moisture availability, competition, predation and extreme weather events that could affect phenology and also modulate the effects of cumulative heat units or photoperiod (Forrest \& Thomson, 2011). However, frost damage that results in a reduction in the number of flowers may pose a more severe threat to bumblebee queens than phenological asynchrony (Inouye 2008). If the early spring flowers used by queen bumblebees are damaged, the scarcity of food may affect their survival and ability to found nests. Northern species of bumblebees, such as B. lucorum emerge early and end their hibernation when the day temperature reaches $15^{\circ} \mathrm{C}$ (Pekkarinen \& Teräs 1997; S.-R. V. pers. obs.). The survival of bumblebee queens after emergence is very dependent on the availability of nectar and temperature, both of which can affect the risk of starvation. Overwintering insects that have a tight energy budget are likely to be especially vulnerable to an increase in temperature (Hahn \& Denlinger, 2011). In order to determine the effects of temperature changes on the survival and long term viability of bumblebee populations it is necessary to monitor bumblebees during spring over time periods of several years.

ACKNOWLEDGEMENTS. We would like to thank M. Haatanen and the technical staff of the University of Turku, Section of Ecology for their assistance. We thank also the anonymous reviewers who helped to improve the manuscript. This study was funded by Maj and Tor Nessling Foundation and University of Turku Foundation (SRV), Emil Aaltonen Foundation, and Kone Foundation (JS).

\section{REFERENCES}

Alford D.V. 1978: The Life of the Bumblebee. Davis-Poynter, London, $80 \mathrm{pp}$.

Beekman M., van Stratum P. \& Lingeman R. 1998: Diapause survival and post-diapause performance in bumblebee queens (Bombus terrestris). — Entomol. Exp. Appl. 89: 207-214.

BHATTACHARYYA S.K. 1962: Laboratory studies of the feeding habits and life cycles of soil-inhabiting mites. - Pedobiologia $\mathbf{1}$ : 291-298. 
Chmielewski W. \& Baker R.A. 2008: Mites (Acarina) phoretic on some common bumblebee species (Bombus spp.) from the Puławy area (South-Eastern Poland). - J. Apic. Sci. 52: 37-46.

EICKWORT G.C. 1994: Evolution and life-history patterns of mites associated with bees. In Houck M.A. (ed.): Mites: Ecological and Evolutionary Analyses of Life-history Patterns. Chapman and Hall, New York, pp. 218-251.

ForRest J.R.K. \& Thomson J.D. 2011: An examination of synchrony between insect emergence and flowering in Rocky Mountain meadows. - Ecol. Monogr. 81: 469-491.

Forster-Johnson A.P. 2002: Bumblebee queens form part of the spring diet of the Great tit (Parus major L.) in southern Finland. - Entomol. Mon. Mag. 138: 138.

Free J.B. \& Butler C.G. 1959: Bumblebees. Collins, London, $208 \mathrm{pp}$.

Hahn D.A. \& Denlinger D.L. 2011: Energetics of insect diapause. - Annu. Rev. Entomol. 56: 103-121.

Huck K., Schwarz H.H. \& Schmid-Hempel P. 1998: Host choice in phoretic mite Parasitellus fucorum (Mesostigmata: Parasitidae): which bumblebee caste is the best? - Oecologia (Berlin) 115: $385-390$.

Hyatт K.H. 1980: Mites of the subfamily Parasitinae (Mesostigmata: Parasitidae) in the British Isles. - Bull. Brit. Mus. Nat. Hist. (Zool.) 38: 237-378.

Goulson D. 2010: Bumblebees: Behaviour and Ecology, 2nd ed. Oxford University Press, New York, 254 pp.

HeInRICH B. 1975: Thermoregulation in bumblebees. II. Energetics of warmup and free flight. - J. Comp. Physiol. 96: 155166.

INOUYE D.W. 2008: Effects of climate change on phenology, frost damage, and floral abundance of montane wildflowers. Ecology 89: 353-362.

IPCC 2013: Climate Change 2013: The Physical Science Basis. http://www.ipcc.ch/report/ar5/wg1/\#.UkwOoKyAmrA (site visited 2. Oct 2013).

KARG W. 1993: Acari (Acarina). In: Milben-Parasitiformes (Anactinochaeta) Cohors Gamasina Leach - Raubmilben. 2nd ed. Die Tierwelt Deutschlands 59, G. Fischer, Jena, 523 pp.

Koulianos S. \& Schwarz H.H. 1999: Reproduction, development and diet of Parasitellus fucorum (Mesostigmata: Parasitidae), a mite associated with bumblebees (Hymenoptera: Apidae). $-J$. Zool. (London) 248: 267-269.

Lepais O., Darwill B., O’Connor S., Osborne J.L., Sanderson R.A., Cussans J., Goffe L. \& Goulson D. 2010: Estimation of bumblebee queen dispersal distances using sibship reconstruction method. - Mol. Ecol. 19: 819-831.

LindQuist E.E., Krantz G.W. \& Walter D.E. 2009: Order Mesostigmata. In Krantz G.W. \& Walter D.E. (eds): A Manual of Acarology. Texas Tech University Press, Lubbock, TX, pp 124-232.

MACIOR L.W. 1968: Bombus (Hymenoptera, Apidae) queen foraging in relation to vernal pollination in Wisconsin. - Ecology 49: $20-25$.
MACIOR L.W. 1994: Pollen-foraging dynamics of subalpine bumblebees (Bombus Latr.). — Plant Spec. Biol. 9: 99-106.

Mašań P. \& StAnKo M. 2005: Mesostigmatic mites (Acari) and fleas (Siphonaptera) associated with nests of mound-building mouse, Mus spicilegus Peteńyi, 1882 (Mammalia, Rodentia). - Acta Parazitol. 50: 228-234.

MicherdZIŃski W. 1969: Die Familie Parasitidae Oudemans, 1901 (Acarina, Mesostigmata). PWN, Kraków, 690 pp.

Pekrarinen A. \& Teräs I. 1977: On the Finnish bumblebees and cuckoo bumblebees. - Luonnon Tutkija 81: 1-24 [in Finnish].

Pereboom J.J.M. 2000: The composition of larval food and the significance of exocrine secretions in the bumblebee Bombus terrestris. - Insect. Soc. 47: 11-20.

Pereboom J.J.M., Velthuis H.H.W. \& Duchateau M.J. 2003: The organisation of larval feeding in bumblebees (Hymenoptera, Apidae) and its significance to caste differentiation. - Insect. Soc. 50: 127-133.

RichaRdS L.A. \& RichaRDS K.W. 1976: Parasitid mites associated with bumblebees in Alberta, Canada (Acarina: Parasitidae; Hymenoptera: Apidae). II. Biology. - Univ. Kans. Sci. Bull. 51: $1-18$.

Rożej E., Witaliński W., Szentgyörgyi H., Wantuch M.W., Moroń D. \& Woyciechowski M. 2012: Mite species inhabiting commercial bumblebee (Bombus terrestris) nests in Polish greenhouses. - Exp. Appl. Acarol. 56: 271-282.

Schmid-Hempel P. 1998: Parasites in Social Insects. Princeton University Press, Princeton, NJ, 392 pp.

Schwarz H.H. \& Huck K. 1997: Phoretic mites use flowers to transfer between foraging bumblebees. - Insect. Soc. 44: 303-310.

Schwarz H.H., Huck K. \& Schmid-Hempel P. 1996: Prevalence and host preference of mesostigmatic mites (Acari: Anactinochaeta) phoretic on Swiss bumble bees (Hymenoptera: Apidae). - J. Can. Entomol. Soc. (Suppl.) 69: 35-42.

Sladen F.W.L. 1912: The Humble-bee: Its Life-history and How to Domesticate it. MacMillan, London, $124 \mathrm{pp}$.

Sorvari J., Haatanen M.-K. \& Vesterlund S.-R. 2011: Combined effects of overwintering temperature and habitat degradation on the survival of boreal wood ant. - J. Insect Conserv. 15: 727-731.

Stelzer R.J., Carlton M., Chittka L. \& Ings T.C. 2010: Winter active bumblebees (Bombus terrestris) achieve high foraging rates in urban Britain. - PLoS One 5: e9559. doi:10.1371/ journal.pone.0009559.

Vogt D.F., Heinrich B., Dabolt T.O. \& McBath H.L. 1994: Ovary development and colony founding in subarctic and temperate-zone bumblebee queens. - Can. J. Zool. 72: 1551-1556.

Washitani I., Kato M., Nishiniro J. \& Suzuki K. 1994: Importance of queen bumble bees as pollinators facilitating intermorph crossing in Primula sieboldii. - Plant Spec. Biol. 9: 169-176.

Received October 4, 2013; revised and accepted January 16, 2014 Prepublished online April 4, 2014 